\title{
Christian Education in the Information of Era Openness with a Faith of Community Approach
}

\author{
Indah Sriwijayanti \\ STAKN Palangka Raya, Jl. Tampung Penyang, RTA Milono km 6 Palangka Raya, Indonesia. \\ indahsriwijayanti@yahoo.co.id
}

\begin{abstract}
Abstrack. Christian education is the task of the church in educating the congregation so that they hold fast to their faith. In the midst of information openness, Christians often get confused and doubt by the many different points of view. The emergence of a lot of fake news, hoaks and hate speech on social media which is one side of information disclosure has a significant impact on the life of the faith of the church. Christian education is a means of the church to remain present as a helper of the congregation so that faith and hope continue to grow in a situation of uncertainty in the midst of information disclosure. The faith community approach in Christian education is a learning process in the participation of the community of faith that aims to help the congregation find meaning in its presence in the middle of the world as an authentic person in its relations with others, the church and the world.
\end{abstract}

Keywords : Christian Education, Faith of Community Approach and The Information of Era Openness

\section{Introduction}

The presence of the internet is an entry point for information openness in every line of human life. Each person is facilitated to get access to the widest possible information as long as the desired data is connected to the internet network. The swift flow of information assumes not only that there is a positive side, but also a negative side that is easily accessible to everyone. At this point then the era of double-faced information disclosure. On one hand it is a very open opportunity for everyone to increase knowledge. On the other hand, the large amount of information makes it difficult for many people to sort out what is right and what is wrong.

The process of Christian education cannot be separated from the context in which it is located. From this context the faith of the church is continually renewed to have more impact on social transformation in society. The era of information disclosure is the context of Christian education today. A world filled with uncertainty, worry and fear is a challenge of faith that must be responded by church people. In the form of reflection the church sees the world as a continuous means of God's love. The church's involvement with the world context in God's mission for world peace through fulfilling hope, the future and empowering Christian education fulfills its purpose. Because Christian faith is a serious struggle with a constantly changing and enigmatic world. This is a challenge for the church to remain faithful in change, of course how also the church contributes to restore and bring God's justice in the midst of the world. Woro I Tobing (2012) in his thesis on the spirituality of the younger generation in the digital age illustrates how the younger 
generation is currently in a state of losing the spirit of fellowship in the church, because the church itself is considered less able to meet the needs of young people in the digital age in the search for meaning in life. This happens because the church falls to mere routine and formality, it makes the younger generation reject the fellowship in the church or move around the beautiful place of worship without ever being able to make sense of the life of faith that is rooted in a community.

The challenge of the church in the era of information disclosure is how to do theology in the midst of changing times. The new paradigm in theology becomes a necessity for the church to do so that it still gets a space in the middle of the congregation's life that is increasingly open with various information. Christian education is a means of theology of the church in proclaiming God's greetings in the context of the present. Theological reflection becomes the church's way of producing contextual theology according to the needs of the times. Theological reflection in the form of action-reflection becomes an effort to transform the church in a wider society that is in the context of the era of information openness.

\section{Method}

\subsection{Methodology}

This paper focus on the important role of Christian education in the midst of information disclosure. The intended role is that the church remains a source of faith for the congregation in finding meaning in life in the midst of information disclosure. Because Christian education is a process that engages the church for its congregation in the face of a constantly changing world. To achieve this goal an understanding of (1) Christian education, (2) the faith community approach, (3) the concept of information era oppeness becomes a fundamental theory to achieve the objectives of this study. The approach used is the study of literature by capturing phenomena that occur in the lives of Christian congregations in contemporary churches around the life of the author.

Theological reflection method is used with the starting point of the experience of the life of Christian congregations in the churches today. The steps used to carry out theological reflection are seeing, judging and acting. At the stage of seeing at Christian education, a careful assessment of social phenomena in this case the impact of information disclosure on the faithful life of the church. The purpose of seeing is found the root of the problem of the struggle of the church is confronted with the disclosure of information so that the expectations of the church continues to grow. The congregation is helped to find liberation from the struggles caused by the era of information disclosure in the form of a transformation of an independent life attitude. Judging is the process of distinguishing God's will in the midst of a congregational concrete situation in matters relating to the information of era openness. Hermeneuitk is the only way to understand the will of God which will later become a light for the praxis of the Christian faith in society. Acting is the process of tracing, applying and evaluating consistently the congregation's expectations of deliverance and the realization of God's will in the church's struggle [1] 


\subsection{Understanding of Christian Education}

Christian education is based on the community of God in the Old Testament. Thus the basics of Christian education have existed since the days of Abraham were called to be the ancestors of God's chosen people. Christian education comes from God himself as a great educator for his people). In the New Testament Jesus became a representative educator of the people through sermons, miracles and role models. The subject of Jesus' teaching is service to each person without discrimination. Jesus' life became a teaching of life that affected many people [2].

Thomas H. Groome as one of the experts in Christian education found anxiety about the polarization tendency between Christian Education and Christian Religious Education which was identified with religious learning in schools. This anxiety begins with the tendency to separate the process of Christian education in a one-sided way. Christian Religious Education as a study of faith in schools seems to be separate from the church's involvement in educating students. Instead Christian education is understood as a process of learning faith in the church alone. This polarization is a wrong concept because, Christian education is a process of pilgrimage of trust which is carried out jointly by believers in relations with the community of faith and other religious communities [3].

According to Mary Elizabeth Moore both Christian religious education and Christianity education are terms that reflect different goals. Christian Religious Education means change and transformation through formal education in schools. While Christian education is related to the continuing legacy of the faith tradition. Meanwhile, according to Hope S. Cannone the terms Christian Religious Education and Christian education are two different things, so assessing these two terms as inappropriate synonyms [4] because they do not show the same meaning. Christian education is education from, for, and diatara Christian communities. Whereas Christian religious education is education from, for and among students who come from various religious groups or faith communities. Thus both Christian education or Christian religious education is a learning activity that is part of the search process in a pilgrimage of trust that leads to the mystery of God's will in human life.

\subsection{Faith of Community Approach}

Conceptually approaches to Christian education are rooted in three main elements; learners' life experiences, scriptures and faith traditions, and conversations between faith experiences with scriptures or faith traditions [5]. The faith community approach is one of four approaches to Christian Religious Education which include; religious teaching approaches, faith development approaches, faith community approaches and transformative approaches [6]. The religious teaching approach describes the formal process of religious teaching in schools which is also a process of finding meaning carried out between the teacher and students in the teaching and learning process at school. In formal religious learning in schools what happens is not just the transfer of knowledge, but also the search for faith from learning activities. The spirituality development approach emphasizes personal transformation that has an impact on community life. In a close relationship with God personally, humans are invited to be involved in answering God's call by taking part in the suffering of the world. While the faith community approach is an 
invitation to participate in a community of people that encourages authentic human development. The existence of people in the community of faith is valued and accepted as is in order to realize relationships between individuals, between communities, and the cosmos. The transformation approach is an approach that emphasizes the involvement of the people in the service of compassion to the world as a manifestation of caring, justice and transformation as a form of Christian Religious Education [7].

The purpose of the faith community approach is to build a community that encourages human development as a whole and helps people become part of the community. The role of the teacher in the faith community approach is as a leader who facilitates small groups and helps the church structure for the life of the church and mission. The categories of students in the approaching faith community are the people (congregation) and the faith community (church). The education process is carried out by serving, reflecting and acting and has the context of a group of congregations that are in a wider community. The faith community approach has implications for service in the form of helping groups and churches to become communities and go out into the world [8].

\subsection{The Information of Era Openness}

The information of era openness that is spread through social media is a new culture that is very dominant influence on the wider community. This culture then replaces other cultures in terms of influencing people [9]. It seems that people prefer to read information from their gadged rather than looking for information through newspapers or magazines. The choices, values, and thoughts of a person at this time are no longer only influenced by family, school and church but are guided more by social media. The bias that can emerge from social media information is in line with viral charm and topic tranding. It does not stop there, a person's choice of the source of information disseminated can be drawn towards the grouping of identities, the political choices of a person who becomes a means of dividing between one group of individuals with another.

In its development the growth of the more sophisticated internet has become a separate issue for human existence. At this time the internet has become a threat to democracy and diversity, not only in Indonesia but also in the world. Because social media such as Facebook, Twitter, Intagram, You Tube etc., have become media that facilitate the sorting, grouping of community members based on what is shared, uploaded, like and followed on social media. Social media has become a system that makes it easy for users to sort friends and opponents. Through social media users are freed to make friends only with groups with the same thoughts, and then create new groups that reinforce personal views.

Initially, the presence of social media is expected to be a "public space" which gives a space of openness and freedom of expression as is the concept of Habermas [10]. According to Habermas, a public space is a space where citizens can actively discuss, consult with equals. In terms of equality in accessing social media it is not restricted, anyone can access social media, anyone can participate as long as they are connected to the internet network. Related to this in developing the existence of social media that occurs far from the concept of Habermas public space. Social media actually facilitates polarization between social groups in the community. The most obvious polarization is ideological polarization. This can be seen at the 2019 Presidential Election event. Indonesian people are polarized to be supporters of number one and number two pairs. This 
polarization is not as simple as it looks because it reflects ideological polarization. This ideological polarization is dangerous for the functioning of a healthy democracy. Because differences of opinion or views are no longer considered normal in democracy. Differences in opinion or meaningful views as opposed to being defeated.

The pattern of problem solving that arises due to differences of opinion or views on social media is to mock each other and niyir. This is done on social media and carried in the real world, perpetuated. As an example of this we can see in the polarization of the Indonesian public into the tadpoles and shucks during the 2019 Presidential Election. How hot the tadpole and shrews debate on social media then continues with the giving of stigma in real life that supporters of serial number one pro government and serial number supporters two as opposition. People are no longer interested in discussing different groups. Even this grouping comes to the point of not caring whether other groups' arguments are right or wrong. The above conditions are a reflection of the times called the post truth [11].

The information of era openness has created an era called the post truth. In post truth facts and truths are no longer important, replaced by information emotionality, and reproduction over and over through social media. The post truth period overrides the truth from actual facts. Alternative facts replace actual facts, and feelings are considered more important than evidence. In the post truth period information dissemination occurs with extraordinary intensity and the emergence of ignorance of the truth becomes the norm or something that is considered reasonable. Many people feel happy by living that untruth and choosing it over reality [12]. The pros and cons of the student demonstration in September 2019 are another example of how The information of era openness has left many members of the public led by opinions based on what is seen and read on social media. Of course this is a condition that is very prone to friction which then causes divisions in the community. Society loses its place of reference which is true because it is as if everyone can make news, everyone can make opinions that can be read by others.

This information flood in the information of era openness has a number of social impacts. The problem faced is not the difficulty in getting news or information, rather the amount of information makes people less able to digest the correct information. As in the post-truth era, facts have no effect in shaping public opinion compared to personal emotions and beliefs (Kharisma, 2017:77-78). In the information of era openness, there are several conditions that are characteristic of post-thruth. First, is the emergence of fake news or false news, false news is a form of artificial news or fake news which is not based on facts, facts or truth. Second, hoaxes are initially hoaxes or stories that are made to make fun of or deliberately confuse recipients with the intention of joking. But then the meaning of hoaxes shifted from making hoax news with the aim of joking to hoax news with serious goals. Third, hate speech is verbal behavior and symbolic actions that intentionally express anti-starch actions, extreme hatred towards certain individuals or groups [13].

This information flood in the information of era openness has a number of social impacts. The problem faced is not the difficulty in getting news or information, rather the amount of information makes people less able to digest the correct information. The church today is in an era of information disclosure. The online world connected by the internet creates confirmation and polarization biases. Virtual reality does not only exist in cyberspace, but also in the reality of everyday life that is when images have replaced reality [14]. The existence of the internet is believed to provide enough knowledge but what happens is a sea of confusing information. As said by Baudrillard about the internet which has created an era where a lot of information with 
meanings is receding [15]. Much information provided by the internet can be information that we do not need, a lot of information but only rubbish, resulting in difficulties in finding meaning and knowledge. In many cases the internet has become an instrument for spreading primordial ideas based on ethnicity or religion [16]. As democracy comes from the conversation, experience and understanding with a community. Christian Religious Education is also a conversation between the faith experience of the church and the source of faith in presenting a just and hopeful future. The term conversation presupposes that in the implementation of Christian Religious Education there is a willingness to hear the struggles and challenges faced by the congregation in their respective contexts so that the source of faith can be lived by the congregation in daily life.

\section{Result and Discussion}

At the stage of theology reflection seeing Christian education see how the fundamental anxiety experienced by the congregation in the face of openness of information that is closely related to the posth truth is confusion in determining what is right and what is wrong? where are the actual facts and where are fake news, hoaxes and hate speech? This condition arises due to the flood of information received by the congregation through social media. This confusion often affects the fragility of faith, even to the shallowness of the faithful life of the church. The most actual example related to church life in Indonesia is the viral Yahya Waloni some time ago has made many members of the church confused to ascertain the truth of the statements made on social media by the concerned. Even though Yahya Waloni virus finally arrived at the meeting point that the person concerned had committed a lie or fake news the church could not get out of hand and said it was an unimportant issue, because the restlessness of the congregation when watching, reading the news about Yahya Waloni was carried away in real life.The church in this case should be present as a community of faith that becomes a space for its members to rediscover the meaning of the life of faith in the midst of the information flow that destabilizes faith.

The church's presence in the era of information openness is the relevance of liberation theology and creation theology. The root of liberation theology is human humanity. Community of faith becomes a means for congregations to understand who they are. This presupposes that the congregation in the faith community understands their vocation as an agent of social change who has a correct understanding of who humans are. Because from him a true understanding of who humans are shared so that in this era of information openness the congregation still holds to the view of the urgency of humanizing humans. The theology of creation presented by the church is a form of acceptance of the diversity of the people as well as an expression of the willingness of the church to be a meeting place between various people in which its unity is united in a commitment to realize the kingdom of God in the middle of the world [17].

As a faith community in the era of information disclosure, the church must have a unique and permanent identity. By making the church realize who it is and realize its purpose. Because unclear identity causes the church to act erratically, even limping in the sense of not holistic. This causes discomfort, reduced congregational participation; church participation decreases, the church's inner involvement decreases [18]. At the stage of theology reflection judging Christian education see how The community of faith is a place for recipients and proclaimers of the good 
news, which is the gospel of Jesus Christ. The gospel of Jesus Christ as good news is excitement for those who receive it and also the preacher so that joy is a hallmark in church life, always optimistic, energetic not discouraged, but has principles and is brave. It has a tradition of lovers of the poor and suffering; never afraid, brave and sincere. Solidarity with those who are poor, weak, suffering, being pursued is the principle of a true Christian attitude. namely by doing real help and lift them [19].

The context of the era of information disclosure leads the church to arrive at the question of what is its mission in the middle of the world? In a confused and fragile society due to the swift flow of information from social media, the church is characterized by excitement and having a tradition of alignment with the poor is the identity of the relevant church. Joy is a characteristic of the community of faith in the context of information disclosure, because the truth of the Word of God in Jesus Christ has become a means for congregants to accept their existence as humans without fear. Humanity is limited, sinful and doubtful, but through Jesus God greets and accepts people. Through Jesus Christ, human existence is humanized. Tradition in favor of the poor is an eternal calling for the existence of the church in the middle of the world. This is an expression of equality as the theology of creation reflects equality among all creatures created by God. Social media may create polarization in society, but the faith community chooses to stand together with those who are poor.

At the stage of theology reflection acting Christian education see how in the midst of an era of information openness, a faith community that has a clear identity and characteristics is a helper for the congregation to arrive at the core of its existence in the middle of the world, namely the fullness of life. The fullness of life as the process of achieving the life of faith leads to a continuous effort towards an intimate fellowship between man and God. Through the fullness of life or spirituality, the church is directed to refocus on the meaning or essence of its existence in the middle of the world. The community of faith becomes a means of aligning the challenges that arise from the post truth and the vocation of the life of the church in the midst of the world. Awareness of the meaningful presence of every believer in the world helps people hold fast to their faith in Jesus Christ. Achievement of life's fullness enables the congregation to be able to share and cheerfully welcome the existence of others who have different views, ideologies and political choices both on social media or in the real world. Because the congregation realizes the calling of the fullest life of the faithful congregation is the partiality of those who are the poorest and most miserable. As Jesus first stated his partiality to them, the community of faith for the congregation is home to find the vocation of life.

\section{Conclusion}

The era of information openness is the context in which the church is today. The era of information openness is a church challenge because it can bring positive and negative influences on church life. In the era of information openness the church was not in a position to choose to accept or reject. The right attitude taken by the church in the era of information openness is dialectical. The church is not immersed in the swift flow of information by becoming spreading fake news, hoaxes and hate speeches on various issues that develop in the community. The church 
takes the position as an alternative community that is a role model for the congregation in responding to Fake news, hoak and hate speech. First the church needs to live more the theology of liberation and theology of creation in the midst of an era of information disclosure. Liberation theology presupposes that there is respect for human values for everyone. Every person is valuable in himself without manipulative prerequisites as in Fake news, hoak and hate speech. Theology of creation is the assumption that all creation comes from God. Originating from God means that there is a uniqueness that is worth equality before God, namely as a creation. Thus in the era of information openness, the diversity of views does not necessarily mean to demean others who disagree.

\section{References}

[1] Seymour, Jack L.( 1997). Maping Christian Education. Nashville: Abingdon Press, 33-34

[2] Homrighausen, E.G dan Enklaar, I.H. (2015). Pendidikan Agama Kristen. Jakarta: BPK GM, 3-6

[3] Antone, Hope S. (2010). Pendidikan Kristiani Kontektual. Jakarta: BPK GM, 31

[4] Antone, Hope S. (2010). Pendidikan Kristiani Kontektual. Jakarta: BPK GM, 33

[5] Seymour, Jack L. (1997). Maping Christian Education. Nashville: Abingdon Press, 21

[6] Seymour, Jack L. (1997). Maping Christian Education. Nashville: Abingdon Press, 21

[7] Seymour, Jack L. (1997). Maping Christian Education. Nashville: Abingdon Press, 15

[8] Seymour, Jack L. (1997). Maping Christian Education. Nashville: Abingdon Press, 18

[9] Kellner, Douglas. (2010). Budaya Media . Yogyakarta: Jalasutra, 10

[10] Alimi, Moh Yasir. (2018). Mediatisasi Agama Post Thurt dan Ketahanan Nasional.Yogyakarta: LkiS, 62

[11] Alimi, Moh Yasir. (2018). Mediatisasi Agama Post Thurt dan Ketahanan Nasional.Yogyakarta: LkiS, 67

[12] Alimi, Moh Yasir. (2018). Mediatisasi Agama Post Thurt dan Ketahanan Nasional.Yogyakarta: LkiS, 65

[13] Alimi, Moh Yasir. (2018). Mediatisasi Agama Post Thurt dan Ketahanan Nasional.Yogyakarta: LkiS, 67

[14] Hardiman, Budi. (2002). Lubang Hitam Kebudayaan. Yogyakarta: Kanisius, 83

[15] Hardiman, Budi. (2002). Lubang Hitam Kebudayaan. Yogyakarta: Kanisius, 83

[16] Hardiman, Budi. (2002). Lubang Hitam Kebudayaan. Yogyakarta: Kanisius, 94

[17] O'Gorman, Robert T., (1997). "The Faith Community", dalam Mapping Christian Education. Nashville: Abingdon Press, 41

[18] Hendrik, Jan. (2002). Jemaat Vital dan Menarik.Yogyakarta: Kanisius, 172

[19] Hendrik, Jan. (2002). Jemaat Vital dan Menarik.Yogyakarta: Kanisius, 174 